\title{
Yield performance and leaf nutrient levels of coffee cultivars under different plant densities
}

\author{
Edison Martins Paulo'; Enes Furlani Jr. ${ }^{2 *}$ \\ ${ }_{2}^{1}$ APTA/DDD, Rod. Raposo Tavares, km 561, C.P. 298 - 19015-970 - Presidente Prudente, SP - Brasil. \\ ${ }^{2}$ UNESP - Depto de Fitotecnia, Av. Brasil, 56 - 15385-000 - Ilha Solteira, SP - Brasil. \\ *Corresponding author < enes@agr.feis.unesp.br>
}

\begin{abstract}
Coffee (Coffea Arabica L.) plantations using adapted cultivars to regional environmental conditions with optimal plant population density and adequate nutrition are expected to show high yield responses. The triennial production and leaf macronutrient concentrations of four coffee cultivars were studied under different plant population densities. Catuaí Amarelo (IAC 47), Obatã (IAC 1669-20), Acaiá (IAC 474-19) and Icatu Amarelo (IAC 2944) were planted in densities of 2,500; 5,000; 7,519; and 10,000 plants ha ${ }^{-1}$ with one plant per hole and two plants per hole in the 2,500 plant ha ${ }^{-1}$. Plants were homogeneously fertilized without liming. As the population density increased the triennial coffee productivity increased, the yield per plant decreased, and leaf concentrations of phosphorus $(\mathrm{P})$, potassium $(\mathrm{K})$ and sulfur $(\mathrm{S})$ increased. Coffee plants under dense systems presented equal or higher leaf macronutrient concentrations compared to the plants under conventional population. Taller cultivars presented the highest nutrient concentration values, and Obatã, a dwarf cultivar, the lowest values. Higher coffee yields and lower leaf P, Ca and S concentrations were observed in plots with one plant compared to the plots with two plants. In general, the coffee cultivars had leaf $\mathrm{N}$ and $\mathrm{S}$ concentrations above the reference limits reported in the literature, but leaf concentrations of other macronutrients were within adequate ranges.
\end{abstract}

Key words: dense system, nutrition

\section{Produtividade e níveis foliares de nutrientes em cultivares de café sob diferentes populações de plantas}

\begin{abstract}
RESUMO: Cultivares de cafeeiro (Coffea Arabica L.) adaptadas às regiões de cultivo, com população de plantas otimizada e adequado estado nutricional são premissas para a obtenção de produções elevadas de café. Estudouse a produção trienal de café e o teor foliar de macronutrientes de cultivares de cafeeiro em função das densidades de plantio. Foram utilizados os cultivares Catuaí Amarelo (IAC 47), Obatã (IAC 1669-20), Acaiá (IAC 474-19) e Icatu Amarelo (IAC 2944) nas populações de 2.500 plantas ha ${ }^{-1}$ com duas plantas por cova; e, $5.000,7.519$ e 10.000 plantas ha ${ }^{-1}$ com uma planta por cova. As plantas foram adubadas de modo homogêneo, porém, sem calagem. À medida que a população de cafeeiros aumentou, a produtividade trienal de café aumentou, a produção de frutos por planta diminuiu e os teores foliares de fósforo $(\mathrm{P})$, potássio $(\mathrm{K})$ e enxofre $(\mathrm{S})$ aumentaram. Nos cafeeiros sob adensamento encontrou-se igual ou maior teor de macronutrientes do que naqueles sob espaçamento convencional, sendo que os maiores teores foram observados nas cultivares de porte alto, e os menores, na cultivar Obatã, de porte baixo. Nos cafeeiros das covas com uma planta observou-se maior produção de café e menores concentrações de $\mathrm{P}, \mathrm{Ca}$ e $\mathrm{S}$ do que naqueles das covas com duas plantas. No geral, os cultivares e as populações de cafeeiros estavam com teores de $\mathrm{N}$ e $\mathrm{S}$ acima dos limites de referência citados na literatura, mas com teores dos demais macronutrientes dentro da faixa adequada.

Palavras-chave: adensamento, nutrição
\end{abstract}

\section{Introduction}

Potentially high yielding and regionally adapted coffee (Coffea Arabica L.) cultivars planted under dense system are important strategies to obtain higher coffee productivity. The interaction between coffee plants and the environment is evidenced when selected high yielding cultivars - with desirable agronomic characteristics, same age and growing simultaneously in the same field area - show different yields (Siqueira et al., 1983; Valarini, 2005). In as much, many authors have reported higher coffee yields under dense plant population systems
(Camargo et al., 2000; Miguel et al., 2000; Pavan et al., 1999; Siqueira, 1983).

Coffee yield increases are expected as a result of cultivar selection and optimal plant density and management. As a consequence, higher plant demand for soil nutrients, higher nutrient exportation at fruit harvest, and higher amounts of fertilizers are expected. However, Huxley and Cannell (1970) observed that the increase on coffee plantation mineral requirements is not proportional to the increase on plant populations. Hence, Huxley and Cannell (1970) recommended the fertilization in an area basis for dense coffee plantations and not 
per plant hole as used in the traditional systems (Rea et al., 1998). Under these circumstances, a plantation nutritional status can be assessed by chemical leaf analysis and interpretation of leaf nutrient concentrations (in a dry basis) by means of qualitative nutrient range scales adequate for the culture under study (Reuter and Robinson, 1998; Jones Jr. et al., 1991; Bergmann, 1992; Malavolta et al., 1993; Mills and Jones Jr., 1996; Malavolta et al., 1997; van Raij et al., 1997; Matiello, 1997). The leaf nutrient analysis together with soil analysis is important tool for the recommendation of coffee plantation balanced and economic fertilization.

The objective of this study was to evaluate the yields and leaf macronutrient concentrations of coffee cultivars under different plant densities at the same level of fertilization.

\section{Material and Methods}

The study herein was carried out in Adamantina,

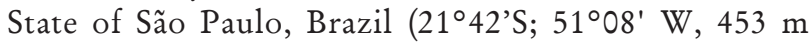
a.s.1.), Cwa climate in Köeppen classification, in an Oxisol (Prado et al., 2003). Soil physical and chemical characteristics of samples collected at $0-0.2 \mathrm{~m}$ depth before the experiment period are presented in Tables 1 and 2 , respectively.

The experimental design was in randomized complete blocks, arranged in split-plots, and three replications. The plots consisted of four population densities, and the subplots of four coffee cultivars. Two dwarf cultivars - Catuaí Amarelo (IAC 47) and Obatã (IAC 166920) - and two tall cultivars - Acaiá (IAC 474-19) and Icatu Amarelo (IAC 2944) - were planted in population densities (in plants per hectare): 2,500 (1,250 holes, two plants per hole, spaced $2 \mathrm{~m}$ from each other); 2,500; 5,000; 7,519; and 10,000 plants with one plant per hole, spaced $1.0 \mathrm{~m}$ between plants, and 4.0, 2.0, 1.33 and $1.0 \mathrm{~m}$ between rows, respectively. The experimental unity in all treatments consisted of four rows with six plants per row, in a total of 24 plants per plot.
In May 1995, coffee seedlings were transplanted to the field at the stage of six pairs of leaves and fertilized with $27 \mathrm{~g}$ of $\mathrm{P}_{2} \mathrm{O}_{5}, 11.6 \mathrm{~g}$ of $\mathrm{K}_{2} \mathrm{O}$ and $50 \mathrm{~g}$ of limestone (100\% relative efficiency) and, subsequently from September to March, with $16 \mathrm{~g}$ of N. Mineral fertilization for tree formation and production was applied twice a year (October and April, Table 3). And, coffee fruits were harvested twice a year, in March and July of 1997, 1998 and 1999, when $90 \%$ of the fruits were at the cherry stage (mature fruits). Fruit mass yields were obtained after fruit drying until $12 \%$ water content. Yearly, at the time of each subplot first harvest, a sample of $3.0 \mathrm{~kg}$ of cherry coffee was collected and submitted to the procedures to obtain processed coffee. The processed coffee bean yields were used to estimate the subsequent processed coffee bean yields of all treatments. The experimental unit for fruit harvesting and leaf sampling consisted of the two center lines of each plot (eight plants per plot). Leaf samplings occurred on February $22^{\text {nd }}, 2000$ as follows: from eight plants per plot, two pairs of leaves were collected at the four cardinal points (eight leaves per plant, 64 leaves per plot). The leaf pair collected was the third leaf pair from the apex of fruit branches located at the coffee plant medium third position, showing at least five well-developed leaf pairs. Leaves from each plot were put together (64 leaves) in labeled paper bags (Malavolta et al., 1997) and sent to the laboratory, where leaf samples were submitted to chemical analysis according to Bataglia et al. (1983).

Adequate macronutrient concentration ranges for coffee leaves were used for comparisons among treatments, based on reference values recommended by Reuter and Robinson (1988), Jones Jr. et al. (1991), Bergmann (1992), Malavolta et al. (1993), Mills and Jones Jr. (1996), Malavolta et al. (1997), van Raij et al. (1997) and Matiello (1997).

The data was submitted to analysis of variance and $\mathrm{F}$ test, to investigate differences among variables within treatments: plant densities, cultivars, and groups of tall and dwarf cultivars. Variables with significant variances

Table 1 - Soil chemical analysis of samples collected at 0-0.2 m depth layer.

\begin{tabular}{|c|c|c|c|c|c|c|c|c|c|}
\hline M.O. & $\mathrm{pH}\left(\mathrm{CaCl}_{2}\right)$ & $\mathrm{P}$ & K & $\mathrm{Ca}$ & $\mathrm{Mg}$ & $\mathrm{H}+\mathrm{Al}$ & SB & CTC & V \\
\hline $\mathrm{g} \mathrm{dm}^{-3}$ & & $\mathrm{dm}^{-3}$ & $\ldots$ & & $---\mathrm{mr}$ & $m^{-3}$ & & 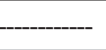 & $\%$ \\
\hline 14.0 & 5.1 & 3.0 & 1.9 & 13.0 & 7.0 & 18.0 & 21.9 & 39.9 & 54.9 \\
\hline
\end{tabular}

$\mathrm{SB}$ (sum of bases) $=\mathrm{Ca}+\mathrm{Mg}+\mathrm{K} ; \mathrm{CTC}=\mathrm{Ca}+\mathrm{Mg}+\mathrm{K}+\mathrm{H}+\mathrm{Al} ; \mathrm{V}$ (base saturation) $=\mathrm{SB} * 100 / \mathrm{T}$

Table 2 - Soil granulometric (particle size) composition (Prado et al., 2003).

\begin{tabular}{lcccccc}
\hline \multirow{2}{*}{ Attribute } & \multicolumn{7}{c}{ Thickness $(\mathrm{cm})$} \\
\cline { 2 - 7 } & $0-25$ & $25-54$ & $54-80$ & $80-108$ & $108-150$ & $150-200$ \\
\hline & 140 & 240 & 240 & 230 & 210 & 220 \\
Clay & 110 & 100 & 100 & 100 & 100 & 110 \\
Silt & 740 & 650 & 650 & 660 & 680 & 660 \\
Fine Sand & 10 & 10 & 10 & 10 & 10 & 10 \\
Coarse Sand & 10 & & & & \\
\hline
\end{tabular}

Sci. Agric. (Piracicaba, Braz.), v.67, n.6, p.720-726, November/December 2010 
Table 3 -Fertilizer sources and quantities yearly applied during the experimental period.

\begin{tabular}{|c|c|c|c|c|}
\hline \multirow{2}{*}{ Nutrient } & \multirow{2}{*}{ Year } & \multicolumn{3}{|c|}{ Source } \\
\hline & & Ammonium sulfate & N-P-K 20.5.20 & Simple Superphosphate \\
\hline & & 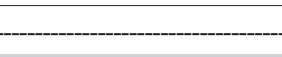 & $\mathrm{kg} \mathrm{ha}^{-1}$ & 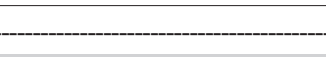 \\
\hline \multirow[t]{4}{*}{$\mathrm{N}$} & $1996 / 97$ & - & 210 & - \\
\hline & $1997 / 98$ & 100 & 200 & \\
\hline & $1998 / 99$ & 100 & 300 & \\
\hline & $1999 / 2000$ & & 200 & \\
\hline \multirow{4}{*}{$\mathrm{P}_{2} \mathrm{O}_{5}$} & $1996 / 97$ & - & 52.5 & - \\
\hline & $1997 / 98$ & - & 50 & 88.8 \\
\hline & $1998 / 99$ & - & 75 & - \\
\hline & $1999 / 2000$ & & 50 & \\
\hline \multirow[t]{4}{*}{$\mathrm{K}_{2} \mathrm{O}$} & $1996 / 97$ & - & 210 & - \\
\hline & $1997 / 98$ & - & 200 & \\
\hline & $1998 / 99$ & - & 300 & \\
\hline & $1999 / 2000$ & & 200 & \\
\hline \multirow[t]{4}{*}{ S } & $1996 / 97$ & - & - & - \\
\hline & $1997 / 98$ & 110 & - & 55.5 \\
\hline & $1998 / 99$ & 110 & - & - \\
\hline & $1999 / 2000$ & - & - & - \\
\hline
\end{tabular}

were submitted to Tukey test $(p<0.05)$ for mean comparisons. Regression analysis was applied to the data obtained with increasing plant populations, following the procedures described by Gomes (1978), using the SAS statistical program (1996).

\section{Results and Discussion}

Obatã and Catuaí Amarelo cvs had the highest triennial processed coffee bean yields per area $(p<0.05)$. Acaiá, the cultivar similar to Catuaí Amarelo cv, did not differ from Icatu Amarelo cv, which is the least productive cultivar under this regional and experimental conditions. As concerned to the coffee yield per plant, Obatã $\mathrm{cv}$ was more productive than Icatu Amarelo cv, but did not differ from the other cultivars. The dwarf cultivars showed higher average triennial processed coffee bean yields (per area and per plant $(p<0.01)$ than the tall ones (Table 5).

In general, the present results corroborated the ones reported in the literature, since Obatã cv showed lower yield than Catuaí, but higher than the Acaiá, Icatu and Novo Mundo yields. The results were also confirmed for the Catuaí cultivar, which exhibited higher yields than Icatu and similar to Acaiá in plantations spaced 4 $\times 4 \times 1 \mathrm{~m}$ and $2 \mathrm{~m}$, with one and two plants per hole, respectively (Siqueira at al., 1983). Under low fertilizing levels the Icatu cv showed higher yields than Catuaí and Acaiá.

The average processed coffee cumulated yield per area, in the period of 1997 to 1999, increased linearly $\left(\mathrm{y}=0.80 \mathrm{x}+3,353, \mathrm{R}^{2}=0.87, p<0.01\right.$, Table 5) with the increasing plant density. Conversely, it was observed decreasing average yield per plant with the increasing plant density and the data fitted a quadratic model $(\mathrm{y}=$ $\left.-0.002 x^{2}+0.1458 x+1,500.3 ; R^{2}=0.92 ; p<0.05\right)$.

The increasing yields with the increasing planting densities were also reported for Acaiá (Siqueira et al., 1983; Pavan et al., 1994, 1997), Catuaí Amarelo (Camargo et al., 2000; Pavan et al., 1994) and Icatu (Pavan et al., 1994; Pavan et al., 1997) cultivars. The decreasing average yields per plant with the increasing plant densities (Table 5) was a consequence of coffee plant competition for water, nutrients and mainly for the active photosynthesis radiation from the canopy apex to the base (Gathaara and Kiara, 1984). Under dense populations coffee flowering and yield concentrates on the plant apex, due to the low light incidence on the plant base. Coffee plant flowering depends on the amount of solar radiation that directly influences the number of fruits per node (Gathaara and Kiara, 1984).

Higher yields were obtained in treatments with 3,650 plants per ha (Table 5). Nevertheless, coffee yields varied similarly among cultivars within different plant populations, i.e., no interaction $(p>0.05)$ between cultivars and plant populations was observed (Table 5). However, Camargo et al. (2000) observed higher yields of Catuaí Amarelo under different spacing between lines, but using one plant per hole.

Coffee cultivars differed $(p<0.01)$ for $\mathrm{N}, \mathrm{P}, \mathrm{Mg}, \mathrm{S}$ and $\mathrm{K}$ leaf concentrations $(p<0.05)$, but not for leaf $\mathrm{Ca}$ (Table 6). Obatã had lowest leaf macronutrient concentrations, but did not differ from Catuaí Amarelo for leaf $\mathrm{K}, \mathrm{Mg}$ and $\mathrm{S}$ and from Acaiá leaf K. Catuaí Amarelo had lower $\mathrm{Mg}$ and $\mathrm{S}$ concentrations than Acaiá; and higher $\mathrm{P}$ and lower $\mathrm{Mg}$ than Icatu Amarelo. Similar leaf ma- 
Table 4 - Reference values of adequate macronutrient concentrations for coffee leaves, according to some authors.

\begin{tabular}{lcccccc}
\hline Authors & $\mathrm{N}$ & $\mathrm{P}$ & $\mathrm{K}$ & $\mathrm{Ca}$ & $\mathrm{Mg}$ & $\mathrm{S}$ \\
\hline & & & & & \\
\hline
\end{tabular}

cronutrient concentrations were found between Icatu Amarelo and Acaiá. The tall cultivars (Acaiá and Icatu Amarelo) had higher leaf $\mathrm{N}, \mathrm{Mg}, \mathrm{S}(p<0.01), \mathrm{P}$ and $\mathrm{K}$ concentrations $(p<0.05)$ than the dwarf cultivars (Catuaí Amarelo and Obatã). In general, all cultivars showed $\mathrm{N}$ and $\mathrm{S}$ concentrations above the adequate reference values (Tables 4 and 6).

Different plant cultivars growing side by side frequently show a large variation in their chemical composition (Epstein, 1975). Coffee leaf nutrient concentration differences among cultivars have been described in several studies (Valarini, 2005) and may be attributed to genetic factors responsible for higher or lower nutrient uptake, translocation and use efficiencies. Acaiá and Catuaí Amarelo cultivars showed leaf $\mathrm{P}$ concentrations below the adequate reference values according to Bergmann (1992) and Malavolta et al. (1997). And Icatu Amarelo and Obatã showed leaf $\mathrm{P}$ concentrations below the adequate values reported by Reuter and Robinson (1988), Bergmann (1992) and Malavolta et al. (1993; 1997), but adequate according to other reference values (Tables 4 and 6).

Acaiá, Catuaí Amarelo and Obatã leaf $\mathrm{K}$ concentrations was considered sufficient according to all criteria proposed, but Icatu Amarelo leaf K was considered excessive according to Bergmann (1992) and Malavolta et al. (1993) (Tables 4 and 6). Acaiá, Catuaí Amarelo and Icatu Amarelo leaf $\mathrm{Ca}$ was insufficient according to reference values of Bergmann (1992) and Malavolta et al., (1997), but adequate according to other reference values. Obatã leaf $\mathrm{Ca}$ concentration was considered sufficient according to Reuter and Robinson (1988) (Tables 4 and 6).

Acaiá, Catuaí Amarelo and Icatu Amarelo leaf Mg concentrations were considered adequate by the reference levels of van Raij et al. (1997) and Matiello et al. (1997), but excessive according to other authors, except for Catuaí Amarelo according to Malavolta et al. (1997). Obatã leaf Mg concentrations were considered above the adequate range according to Malavolta et al. (1993), or insufficient, according to Malavolta et al. (1997), or appropriate by other reference values (Tables 4 and 6).
Table 5 - Triennial processed coffee yields per plant and per unity area; averages over cultivars and plant populations.

\begin{tabular}{|c|c|c|}
\hline \multirow[t]{2}{*}{ Cultivar(c)(1) } & \multicolumn{2}{|c|}{ Coffee yield } \\
\hline & $\mathrm{kg} \mathrm{ha}^{-1}$ & g per plant \\
\hline Acaiá & $6,978.34 \mathrm{bc}$ & $1,474.42 \mathrm{ab}$ \\
\hline Catuaí Amarelo & $8,284.85 \mathrm{ab}$ & $1,649.71 \mathrm{a}$ \\
\hline Icatu Amarelo & $6,596.60 \mathrm{c}$ & $1,317.42 \mathrm{~b}$ \\
\hline Obatã & $8,561.93 \mathrm{a}$ & $1,631.11 \mathrm{a}$ \\
\hline F cultivar & $7.23 * *$ & $4.83 \% *$ \\
\hline $\mathrm{Fp} \times \mathrm{c}$ & $1.67 \mathrm{~ns}$ & $1.32 \mathrm{~ns}$ \\
\hline \multicolumn{3}{|l|}{ Population } \\
\hline \multicolumn{3}{|l|}{ plants hole ${ }^{-1} \mathrm{ha}^{-1}$} \\
\hline $1250^{(2)}$ & $3,941.32$ & $1,576.53$ \\
\hline 5000 & $1,828.66$ & $4,571.64$ \\
\hline 7519 & $10,148.60$ & $1,349.73$ \\
\hline 10000 & $10,369.42$ & $1,036.42$ \\
\hline \multicolumn{3}{|c|}{ Analysis of variance } \\
\hline F population & 38.42 & 6.06 \\
\hline F LR & $135.03 \% *$ & $13.42 \% *$ \\
\hline $\mathrm{F} Q R$ & $4.75 \mathrm{~ns}$ & $9.49 *$ \\
\hline CV(a) (\%) & 22.85 & 30.70 \\
\hline $\mathrm{CV}(\mathrm{b})(\%)$ & 18.26 & 18.01 \\
\hline
\end{tabular}

${ }^{1}$ Values followed by the same letter in the column do not differ by Tukey test (0.05). ${ }^{2}$ Two plants per hole. F LR $=F$ test for linear regression. $\mathrm{F} Q \mathrm{QR}=\mathrm{F}$ test for quadratic regression. $\mathrm{ns}=$ non-significant; * significant at $p<0.05 ; * *$ significant at $p<$ 0.01 .

No differences $(p<0.05)$ among population leaf levels were found for $\mathrm{N}, \mathrm{Ca}$ and $\mathrm{Mg}$, but positive and linear effects were observed for $\mathrm{P}(\mathrm{y}=3 \mathrm{E}-0.5 \mathrm{X}$ 1.2676) $\left(\mathrm{R}^{2}=0.64\right), \mathrm{K}(\mathrm{y}=0.0009 \mathrm{x} 17.952)\left(\mathrm{R}^{2}=0.91\right)$, and $\mathrm{S}(\mathrm{y}$ $=5 \mathrm{E}-0.5 \mathrm{X} 2.4688)\left(\mathrm{R}^{2}=0.58\right)(p<0.01$; Table 6$)$. Significant contrasts $(p<0.05)$ were observed between populations of 2,500 plants per hectare spaced $4.0 \times 1.0$ $\mathrm{m}$ with one plant per hole and $4.0 \times 2.0 \mathrm{~m}$ with two plants per hole, for $\mathrm{P}, \mathrm{Ca}$ and $\mathrm{S}$. Leaves from the popu-

Sci. Agric. (Piracicaba, Braz.), v.67, n.6, p.720-726, November/December 2010 
Table 6 - Coffee leaf macronutrient concentrations: averages over coffee cultivars and plant populations.

\begin{tabular}{|c|c|c|c|c|c|c|}
\hline Cultivar (c) & $\mathrm{N}$ & $\mathrm{P}$ & $\mathrm{K}$ & $\mathrm{Ca}$ & $\mathrm{Mg}$ & $\mathrm{S}$ \\
\hline & \multicolumn{6}{|c|}{$\mathrm{g} \mathrm{kg}^{-1(1)}$} \\
\hline Acaiá & $40.45 \mathrm{a}$ & $1.50 \mathrm{ab}$ & $22.76 \mathrm{ab}$ & 10.47 & $4.57 \mathrm{a}$ & $2.99 \mathrm{a}$ \\
\hline Catuaí Amarelo & $39.62 \mathrm{a}$ & $1.54 \mathrm{a}$ & $22.95 \mathrm{ab}$ & 10.51 & $4.11 \mathrm{~b}$ & $2.63 \mathrm{bc}$ \\
\hline Icatu Amarelo & 39.57 a & $1.39 \mathrm{~b}$ & $24.37 \mathrm{a}$ & 10.50 & $4.65 \mathrm{a}$ & $2.81 \mathrm{ab}$ \\
\hline Obatã & $37.11 \mathrm{~b}$ & $1.21 \mathrm{c}$ & $21.62 \mathrm{~b}$ & 9.78 & $3.86 \mathrm{~b}$ & $2.42 \mathrm{c}$ \\
\hline F cultivar & $27.79 * *$ & $23.02 * *$ & $3.54 *$ & $2.74 \mathrm{~ns}$ & $10.57 * *$ & $14.81 * *$ \\
\hline $\mathrm{Fp} \times \mathrm{c}$ & $2.09 \mathrm{~ns}$ & $0.97 \mathrm{~ns}$ & $1.48 \mathrm{~ns}$ & $2.10 *$ & $1.79 \mathrm{~ns}$ & $1.06 \mathrm{~ns}$ \\
\hline \multicolumn{7}{|c|}{ Population (plants hole ${ }^{-1} \mathrm{ha}^{-1}$ ) } \\
\hline $1250^{(2)}$ & 39.06 & 1.34 & 19.99 & 10.43 & 4.44 & 2.64 \\
\hline 5000 & 39.63 & 1.48 & 23.66 & 10.49 & 4.19 & 2.84 \\
\hline 7519 & 39.15 & 1.51 & 24.29 & 10.85 & 4.48 & 2.78 \\
\hline 10000 & 39.76 & 1.50 & 27.75 & 10.18 & 3.99 & 2.93 \\
\hline F population & $0.89 \mathrm{~ns}$ & $12.01 \%$ & $15.40 \% *$ & $2.41 \mathrm{~ns}$ & $3.21 \mathrm{~ns}$ & $9.88^{* * *}$ \\
\hline F LR & $1.39 \mathrm{~ns}$ & $29.05^{* *}$ & $53.46^{* * *}$ & $0.61 \mathrm{~ns}$ & $4.97 \mathrm{~ns}$ & $19.95 \% *$ \\
\hline F QR & $0.16 \mathrm{~ns}$ & $0.01 \mathrm{~ns}$ & $2.14 \mathrm{~ns}$ & $0.06 \mathrm{~ns}$ & $0.83 \mathrm{~ns}$ & $1.33 \mathrm{~ns}$ \\
\hline CV (a) (\%) & 5.22 & 8.52 & 13.63 & 9.84 & 9.23 & 8.90 \\
\hline CV (b) (\%) & 2.70 & 8.34 & 10.12 & 8.28 & 10.47 & 9.05 \\
\hline
\end{tabular}

${ }^{1}$ Values followed by the same letter in the column do not differ by Tukey test $(0.05) .{ }^{2}$ Two plants per hole. F LR $=\mathrm{F}$ test for linear regression. $\mathrm{F} \mathrm{QR}=\mathrm{F}$ test for quadratic regression. $\mathrm{ns}=$ non-significant; * significant at $p<0.05$; $* *$ significant at $p<0.01$.

lation with two plants per hole showed higher macronutrient concentrations (Table 6), probably because this planting technique (two plants per hole) provided greater root efficiency for acquisition of water and nutrients from soil.

Significant interaction between populations and cultivars was found for leaf $\mathrm{Ca}$ concentration $(p<0.05$; Table 7), due to the increasing Obatã leaf $\mathrm{Ca}$ as a linear function of plant density $\left(Y=0.0003 X\right.$ 8.2461) $\left(R^{2}=0.77\right.$; $p<0.01)$. This effect was not observed for the other cultivars $(p>0.05$; Table 7$)$.

The average leaf $\mathrm{N}$ and $\mathrm{S}$ concentrations of all cultivars in different populations were higher than the reference values used for comparisons (Tables 4 and 6). The average leaf $\mathrm{P}$ concentrations of different plant populations were considered adequate according to Jones Jr. et al. (1991), Mills and Jones Jr. (1996), van Raij et al. (1997) and Matiello (1997), who reported adequate values ranging between 1.2 and $2.0 \mathrm{~g} \mathrm{~kg}^{-1}$, but insufficient, according to Bergmann (1992) and Malavolta et al. (1997), who reported limit values of $1.6 \mathrm{~g} \mathrm{~kg}^{-1}$. Plant populations with 7,519 and 10,000 plants per hectare were the only systems where plants showed sufficient $\mathrm{P}$ levels compared to the reference values reported by Reuter and Robinson (1988) and Malavolta et al. (1993) (Tables 4 and 6).

Populations with 2,500 plants had lower leaf $\mathrm{K}$ concentrations than the reference values (Tables 4 and 6), but adequate by the criteria of van Raij et al. (1997), Matiello et al. (1997) and Malavolta et al. (1993); this latter only for the 2,500-population with one plant per hole. However, leaf $\mathrm{K}$ concentrations found in the 10,000-
Table 7 - Analysis of variance of Ca leaf contents: interaction between populations and coffee cultivars.

\begin{tabular}{lccc}
\hline Cultivar & Population vs Cultivars & LR & QR \\
\hline Acaiá & $0.58 \mathrm{~ns}$ & - & - \\
Catuaí Amarelo & $0.41 \mathrm{~ns}$ & - & - \\
Icatu Amarelo & $2.94 \mathrm{~ns}$ & - & - \\
Obatã & $17.94 * *$ & $17.94 * *$ & $1.51 \mathrm{~ns}$ \\
\hline Equation & \multicolumn{3}{c}{$0.0003 \times+8.24$} \\
\hline $\mathrm{R}^{2}$ & \multicolumn{3}{c}{0.77}
\end{tabular}

$\mathrm{LR}=$ linear regression; $\mathrm{QR}=$ quadratic regression; *significant $\mathrm{F}$ test at $p<0.05 ; * *$ significant $\mathrm{F}$ test at $p<0.01 ; \mathrm{ns}=$ non significant $\mathrm{F}$ test.

population were above all reference values. And populations with 5,000 and 7,519 plants per hectare showed adequate leaf K, except for the Bergmann (1992) and Malavolta et al. (1993) criteria, for which the 5,000 and 7,519-populations showed leaf $\mathrm{K}$ values above their limits (Tables 4 and 6).

The average leaf $\mathrm{Ca}$ concentrations were considered insufficient for all populations according to Malavolta et al. (1997), except for the 2,500-population which leaf $\mathrm{Ca}$ was found adequate according to Reuter and Robinson (1988), but insufficient compared to the other authors' limits (Tables 4 and 6). Average leaf $\mathrm{Mg}$ concentrations of 2,500-, 5,000- and 7,519 populations were found adequate according to Malavolta et al. (1997), van Raij et al. (1997) and Matiello et al. (1997), but above the 
adequate limits according to other authors. And the 10,000-population showed leaf $\mathrm{Mg}$ above the limit values according to Malavolta et al. (1993), insufficient according to Malavolta et al. (1997) and adequate according to the other authors (Tables 4 and 6).

The mentioned macronutrient reference values for coffee plants have been used for the interpretation of leaf macronutrient concentrations (stated by Reuter and Robinson, 1988; Jones Jr. et al., 1991; Bergmann, 1992; Malavolta et al., 1993; Mills and Jones Jr., 1996; Malavolta et al., 1997; Matiello, 1997; and van Raij et al., 1997; Table 4) and have resulted different nutritional diagnosis for coffee cultivars and populations. Correa et al. (2001), in the south of Minas Gerais State, also obtained different nutritional diagnosis using the same references (Table 4). Some authors have cogitated about the fact that the nutrient critical levels have been established without taking into account the regional variations for a more accurate assessment, turning difficult to define the most appropriate criterion for the interpretation of leaf analysis results. Nevertheless, assuming the reference value ranges above mentioned, the coffee cultivars planted under 10,000-population treatment showed leaf concentrations within the adequate ranges for $\mathrm{P}$ (1.2-2.0 $\left.\mathrm{g} \mathrm{kg}^{-1}\right), \mathrm{K}\left(18.0-26.0 \mathrm{~g} \mathrm{~kg}^{-1}\right), \mathrm{Ca}\left(7.5-25.0 \mathrm{~g} \mathrm{~kg}^{-1}\right)$ and $\mathrm{Mg}$ (2.5-5.0 g kg-1), and above the adequate range for $\mathrm{N}(23.0-$ $\left.35.0 \mathrm{~g} \mathrm{~kg}^{-1}\right), \mathrm{S}\left(0.2-2.0 \mathrm{~g} \mathrm{~kg}^{-1}\right)$ and $\mathrm{K}$ (Tables 4 and 6).

Nitrogen is considered the main nutrient in coffee plantations under conventional population systems (Gallo et al., 1999). Prezotti and Rocha (2004) pointed out that the use of $\mathrm{N}$-fertilization rates close to $300 \mathrm{~kg}$ $\mathrm{ha}^{-1}$ are common in coffee plantations, despite the fact that an adequate leaf $\mathrm{N}$ concentration of $30 \mathrm{~g} \mathrm{~kg}^{-1}$ can be obtained with only $100 \mathrm{~kg} \mathrm{ha}^{-1}$ of $\mathrm{N}$, even in plots with larger spacing. In this study, leaf $\mathrm{N}$ concentrations exceeded the upper limit of reference value ranges of different authors, for all cultivars and populations (Tables 4 and 6) and this fact was not itself indicative of higher yields, because wide variation on leaf $\mathrm{N}$ concentrations and yields were observed for cultivars under similar conditions (Valarini, 2005). Gallo et al. (1999) emphasized that in shaded and dense systems the effect of N-fertilization may be negative, mainly when the coffee plantation already exhibits an excessive leaf $\mathrm{N}$ concentration.

The results obtained in this work (Table 6) agree with those reported by Prezotti and Rocha (2004), in which leaf $\mathrm{N}$ variation between 31 and $35 \mathrm{~g} \mathrm{~kg}^{-1}$ was not significant in Catuaí Vermelho for N-fertilization rates up to $700 \mathrm{~kg} \mathrm{ha}^{-1}$ and for populations smaller than 10,000 plants per hectare. Prezotti and Rocha (2004) observed that the initial $\mathrm{N}$-rate of $100 \mathrm{~kg} \mathrm{ha}^{-1}$ was sufficient to coffee leaves reach $31 \mathrm{~g} \mathrm{~kg}^{-1}$ of $\mathrm{N}$, even in a 20,000 plant population.

The increasing leaf $\mathrm{P}$ concentration with the increasing population density fitted a first degree equation ( $\mathrm{y}$ $=0.00003 \mathrm{x}+1.2676 ; \mathrm{r}^{2}=0.64$; Table 6) in agreement with the results of Prezotti and Rocha (2004). These authors observed a relationship between the leaf $\mathrm{P}$ vs plant density results and the soil moisture conditions found in more dense population plots, which also provided greater plant shading and biomass accumulation on the soil surface. Such better soil moisture conditions in dense plots allowed higher soil $\mathrm{P}$ diffusion and more efficient $\mathrm{P}$ uptake by plant roots. On the other hand, the solubility of several $\mathrm{P}$ compounds in the soil is determined by soil $\mathrm{pH}$. Considering that phosphates of iron, manganese and aluminum, have low water solubility at low $\mathrm{pH}$, these phosphates are mostly unavailable in acid soils (Pavan and Chaves, 1996). Pavan et al. (1999) observed a soil $\mathrm{pH}$ increase and higher percentage of colonized roots with arbuscular mycorrhizal fungi with the increasing population density. This fact associated to the consequent higher root density, might possibly explain the results related to the higher leaf $\mathrm{P}$ concentrations in coffee plants under increasingly dense systems.

Leaf $\mathrm{K}$ concentrations also increased with the increasing population densities, according to a linear regression equation $\left(y=0.00009 x+17.95 ; R^{2}=0.59\right.$; Table 6), corroborating the results of Prezotti and Rocha (2004). Therefore, the coffee leaf $\mathrm{K}$ positive responses obtained with the increasing plant densities (Table 6) might also be attributed to the higher soil moisture observed in coffee plantations under more dense systems, what favors $\mathrm{K}$ movement by diffusion to the roots. From these results it is possible to infer that higher $\mathrm{K}$ acquisition by coffee plants occurs due to the higher soil moisture and root density observed in dense systems allowing roots to better explore the soil for nutrients.

Some authors have reported a direct relationship between plant spacing and leaf $\mathrm{Mg}$ concentration and the opposite with leaf $\mathrm{K}$, indicating antagonism between both nutrients. Such results were confirmed in the herein study, evidenced by the negative correlation $(p<0.01$; $\mathrm{r}=-0.64$ ) observed between coffee leaf $\mathrm{K}$ and $\mathrm{Mg}$ concentrations. Considering that leaf nutrient concentrations depend on the nutrient availability in the rhizosphere, the results evidenced that the dense coffee plantation systems used more efficiently soil nutrient resources, showing similar or higher leaf nutrient concentrations of coffee plantations under conventional plant density system.

\section{References}

Bataglia, O.C.; Furlani, A.M.C.; Teixeira, J.P.F.; Furlani, P.R.; Gallo, J.R. 1983. Methods of Chemical Analysis of Plants. Instituto Agronômico, Campinas, SP, Brazil. (in Portuguese).

Bergmann, W. 1992. Nutritional Disorders of Plants: Development, Visual and Analytical Diagnosis. G. Fisher, New York, NY, USA.

Correa, J.B.; Reis Jr., R.A.; Carvalho, J.G.; Guimarães, P.T.G. 2001. Evaluation of soil fertility and nutritional status of coffee trees in the southern of the Minas Gerais state. Ciência e Agrotecnologia 25: 1279-1286. (in Portuguese, with abstract in English).

Epstein, E. 1975. Mineral Nutrition of Plants: Principles and Perspectives. University of São Paulo, São Paulo, SP, Brazil. (in Portuguese). 
Gallo, P.B.; van Raij, B.; Quaggio, J.A.; Pereira, L.C.E. 1999. Response of closed coffee plantations to NPK fertilization. Bragantia 2: 341-351. (in Portuguese).

Gathaara, M.P.H.; Kiara, J.M. 1984. M. Factors that influence yeld in close-spaced coffee. 1. ligth, dry matter production and plant water status. Kenya coffee 49: 203-211.

Gomes, F.P. 1978. Experimental Statistics Course. Nobel, São Paulo, SP, Brazil. (in Portuguese).

Huxley, P.A.; Cannel, M.G.R. 1970. Some physiological factors to be considered in intensification. Kennya Coffee 35: 351-4.

Jones Jr., J.B.; Wolf, B.; Mills, H.A. 1991. Plant Analysis Handbook. Micro-Macro Publishing, Athens, GA, USA.

Malavolta, E.; Vitti, G.C.; Oliveira, S.A. 1997. Evaluation of Nutritional Plant Status: Principles and Applications. Potafós, Piracicaba, SP, Brazil. (in Portuguese).

Malavolta, E. 1993. Mineral Nutrition and Fertilization of Coffee: Maximum Economic Yields. Agronomica Ceres, São Paulo, SP, Brazil. (in Portuguese).

Mills, H.A.; Jones Jr., J.B. 1996. Plant Analysis Handbook II. 1996. Micro-Macro Publishing Athens, GA, USA.

Pavan, M.A.; Chaves, J.C.D. 1996. Influence of plant density on soil fertility. International Symposium of Closed Coffee, 1. Londrina, PR, Brazil p. 87-106. (in Portuguese).

Pavan, M.A.; Chaves, J.C.D.; Androcioli Filho, A. 1994. Coffee production under plant population, fertilization and phytosanitary treatment. Turrialba 44: 227-231.

Pavan, M.A.; Chaves, J.C.D.; Smith, R.; Androcioli Filho, A.; Colozzi Filho, A.; Balota, E.L. 1999. High Coffee Population to Improve Fertility of an Oxisol. Department of Agriculture, Brasília, DF, Brazil. p. 459-465. (in Portuguese).

Pavan, M.A., Chaves, J.C.D., Smith, R.A.; Androcioli Filho, A. 1997. Coffee Crop: The System of High Density Planting and Improvement of Soil Fertility. Potafós, Piracicaba, SP, Brazil. p. 1-7. (in Portuguese).
Prado, H.; Tremocoldi, W.A.; Menk, J.R.F. 2003. Detailed Soil Survey of the Regional Center of Technological Development of Agribusiness in Adamantina. São Paulo Department of Agriculture, Campinas, SP, Brazil. (in Portuguese).

Prezotti, L.C.; Rocha, A.C. 2004. Coffee nutrition as a function of plant density and NPK fertilization. Bragantia 63: 239-251. (in Portuguese, with abstract in English).

Reuter, D.J.; Robinson, J.B. 1988. Plant Analysis: An Interpretation Manual. CSIRO, Melbourne, Australia.

SAS Institute. 1996. User's Guide SAS Institute, Cary, NC, USA.

Siqueira, R.; Androcioli Filho, A.; Pavan, M.A.; Chaves, J.C.D. 1983. Plant Density, Pruning of First Branches and Yield of Two Coffee Cultivars and the Hybrid Icatu. Department of Agriculture, Brasília, DF, Brazil. p. 763-769. (in Portuguese).

Valarini, V. 2005. Demand of Nutrients by the Leaves and Fruits in Cultivars of Arabica Coffee. Instituto Agronômico, Campinas, SP, Brazil. (in Portuguese).

Van Raij, B.; Fernandes, R.D.; Oliveira, E.G.; Malavolta, E.; Cervellini, G.S.; Cantarella, H.; Barros, I.; Toledo Filho, J.A.; Pereira, L.C.E.; Gallo, P.B.; Thomaziello, R.A.; Bonini, R.; Costa, T.E. 1997. Coffee. In: Van Raij, B.; Cantarella, J.A.; Quaggio, J.A., Furlani, A.M.C. Recommendations of fertilization and liming for the State of São Paulo. Instituto Agronômico, Campinas, SP, Brazil. (in Portuguese).

Received April 09, 2009

Accepted June 21, 2010 